\title{
Grapevine bacterial canker in the State of São Paulo, Brazil: detection and eradication
}

\author{
Júlio Rodrigues Neto ${ }^{1}$, Suzete A.L. Destéfano ${ }^{1}$, Lucas M.R. Rodrigues ${ }^{2}$, Danilo Souza Pelloso ${ }^{3}$ \& Leonardo \\ da Cruz Oliveira Júnior ${ }^{3}$
}

${ }^{1}$ Laboratório de Bacteriologia Vegetal, Instituto Biológico, 13012-970, Campinas, SP, Brazil; ${ }^{2}$ Departamento de Defesa Fitossanitária, Universidade Estadual Paulista - UNESP, 18603-970, Botucatu, SP, Brazil; ${ }^{3}$ Coordenadoria de Defesa Agropecuária, 17900-000, Dracena, SP, Brazil

Author for correspondence: Júlio Rodrigues Neto, e-mail:julio@biologico.sp.gov.br

\begin{abstract}
Symptoms of bacterial canker of grapevine in the variety Red Globe were observed in August 2009 in an orchard at Tupi Paulista, São Paulo State, Brazil, and the causal agent Xanthomonas campestris pv. viticola was identified by pathological and molecular tests. Eradication procedure was adopted and approximately 4,700 plants were destroyed. A survey was conducted on grape-producing regions in the state of Sao Paulo, which found no other contaminated orchard, and this bacterial species is considered absent in the state.

Key words: Xanthomonas campestris pv. viticola, survey, PCR-RFLP.

RESUMO

Cancro bacteriano da videira no Estado de São Paulo: detecção e erradicação

Sintomas do cancro bacteriano da videira na variedade Red Globe foram observados em agosto de 2009 em pomar de Tupi Paulista, Estado de São Paulo, Brasil, e o agente causal Xanthomonas campestris pv. viticola foi identificado por meio de testes patológicos e moleculares. O procedimento de erradicação foi adotado e aproximadamente 4.700 plantas foram destruídas. Um levantamento realizado nas regiões produtoras do Estado de São Paulo não encontrou nenhum outro pomar contaminado, e essa espécie bacteriana é considerada ausente neste estado.

Palavras-chave: Xanthomonas campestris pv. viticola, levantamento, PCR-RFLP.
\end{abstract}

The grapevine bacterial canker caused by Xanthomonas campestris pv. viticola was first observed in Brazil in 1998, occurring in the region of Petrolina, State of Pernambuco (Malavolta Jr. et al.,1999a), probably introduced by infected propagation plant material imported from India. This bacterial species was further spread to other regions and states in the country (Malavolta Jr. et al., 1999b; Lima et al., 1999; Freire \& Oliveira, 2001; HalfeldVieira \& Nechet, 2006), becoming an important disease with significant losses in production, because the main cultivated varieties like Red Globe, Italy, Rubi, Benitaka, Patricia, Brazil were found to be very susceptible to the pathogen.

In August 2009, an outbreak of grapevine bacterial canker was detected in a property producing grape for table consumption, located at Tupi Paulista county, State of São Paulo, Brazil. In the orchard the variety Red Globe grafted on the rootstock IAC 572 was cultivated and the disease incidence ranged from $70 \%$ to $80 \%$ of plants, but no disease symptoms were observed on the sprouts emerging from rootstocks. Looking at the history of the property it was assumed that the disease had been introduced through infected propagating material for grafting obtained from the
Petrolina region about eight years ago. In the same property another plot was cultivated with Niagara Rosada variety (Vitis labrusca x vinifera hyb.), but no bacterial infection was detected in this field. The symptoms observed in the field were cankers on the twigs as well as brown to black leaf spot lesions surrounded or not by a chlorotic halo, sometimes along the veins, and numerous depressed dark lesions on berries (Figure 1, A-B). In some cases a pale white exudation was observed over the lesions.

The bacteria were isolated through macerating a portion of the infected tissue on a microscope slide with sterile distilled water and streaking the resulting suspension onto Nutrient Agar (NA) plate. After 48-72 hours' incubation at $28^{\circ} \mathrm{C}$, white, smooth and convex colonies were observed on agar medium, selected and transferred to NA and/or Yeast Glucose Agar (GYCA) for to be used on biochemical, molecular and pathogenicity tests.

Pathogenicity tests on vine Red Globe variety were performed with three isolates (IBSBF 2738, 2739 and 2741) in greenhouse conditions. One plant was inoculated with each selected isolate, and three leaves were inoculated per plant. Fully expanded leaves were wounded with multiple needles and inoculated by passing a cotton swab previously 

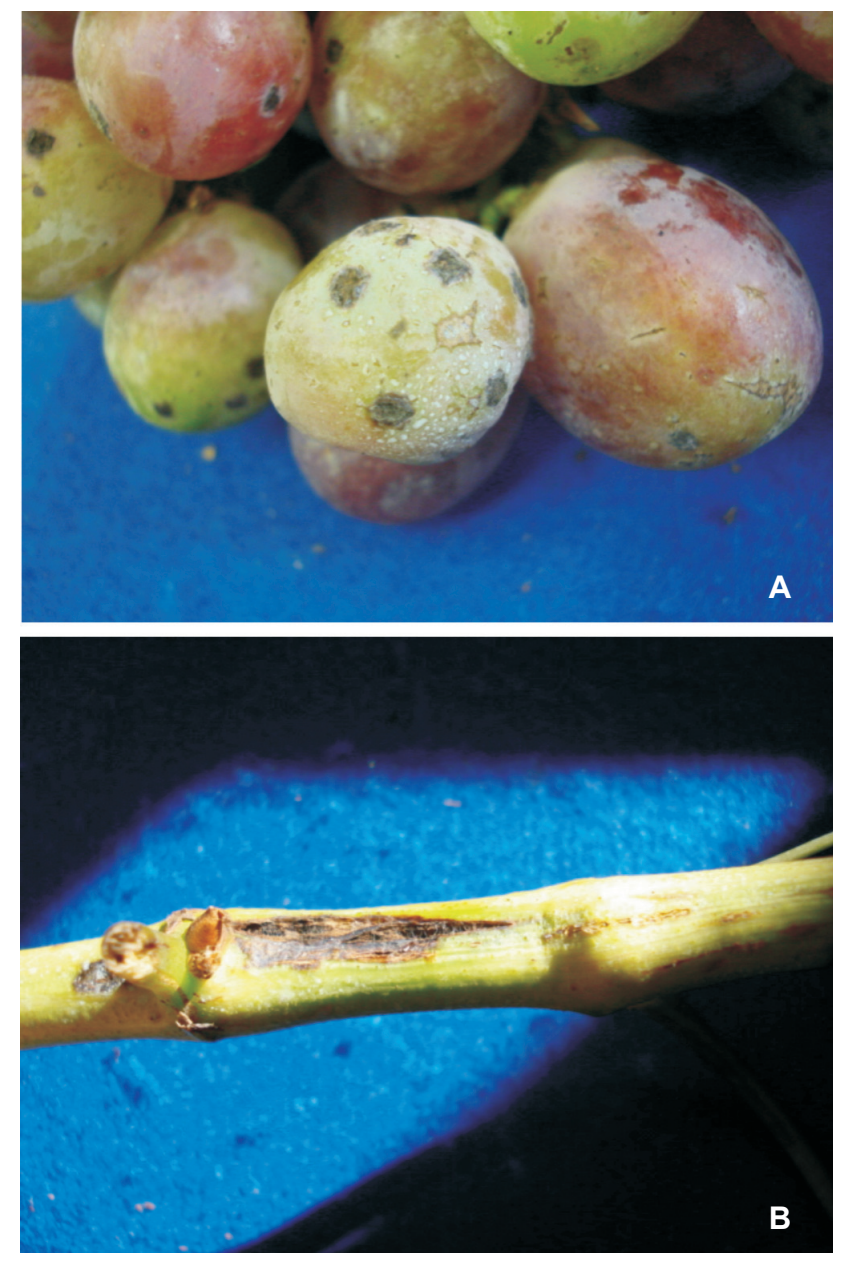

FIGURE 1 - A. Natural symptoms induced by Xanthomonas campestris pv. viticola on berries and $\mathbf{B}$. twig.

immersed in a bacterial suspension (ca. $10^{7} \mathrm{CFU} / \mathrm{mL}$ ) on the lower surface of the leaves. Three weeks after inoculations similar symptoms were observed and identical bacteria were re-isolated.

Seven isolates were used in molecular tests. Genomic DNA was extracted as described by Pitcher et al. (1989). The PCR amplification of the 16S-23S rDNA spacer region was performed as described by Destéfano and Rodrigues Neto (2002). The amplification yielded a unique band of approximately 1.1 kilobase $(\mathrm{kb})$ for all the strains tested. The restriction fragments were separated by electrophoresis in 3\% agarose gels in 1X TAE buffer (Maniatis et al., 1982). The gels were stained with $0.1 \mu \mathrm{g}$ per $\mathrm{mL}$ of $\mathrm{EtBr}$ and then photographed under ultraviolet transillumination using an Alpha Innotech 2200 digital system. The molecular weights of the fragments were determined by comparison with a 100 base pairs (bp) DNA ladder (GE Heathcare). PCR products $(5 \mu \mathrm{L})$ were digested, individually, with each of the following restriction endonucleases Dde I, Hinf I and Hpa II under conditions specified by the manufacturer (Fermentas), and the results showed identical RFLP patterns of the isolates in comparison with the pathovar reference strain of $X$. campestris pv. viticola and with a bacterial strain isolated of plant material from Petrolina, State of Pernambuco, Brazil (IBSBF $1967^{\mathrm{P}}$ and 1926, respectively) (Figure 2).

Grapevine cultivation is economically important for the country and bacterial canker may become a limiting factor for this crop, even having an impact on trade. For this reason $X$. campestris pv. viticola is presently considered a quarantine pest (A2) by the government and it is under regulation ("MAPA, Instrução Normativa n. 52", November/20, 2007). Efforts and control strategies carried out by the Coordination of Plant Protection of the State of Sao Paulo were based on intensive surveillance and eradication measures.

As a result of this eradication campaign, the above mentioned orchard was eradicated and approximately 4700 plants were destroyed, corresponding to five hectares of planting. Surveys were conducted in 2009/2010 in the State of São Paulo in grape-producing regions; a total of 68 orchards were inspected for detection of bacterial canker and no other infected orchard was observed. Thus, the situation of Xanthomonas campestris pv. viticola in the State of Sao Paulo can be described as follows: absent, detected in 2009 on one orchard located at Tupi Paulista county, eradicated and under official control.

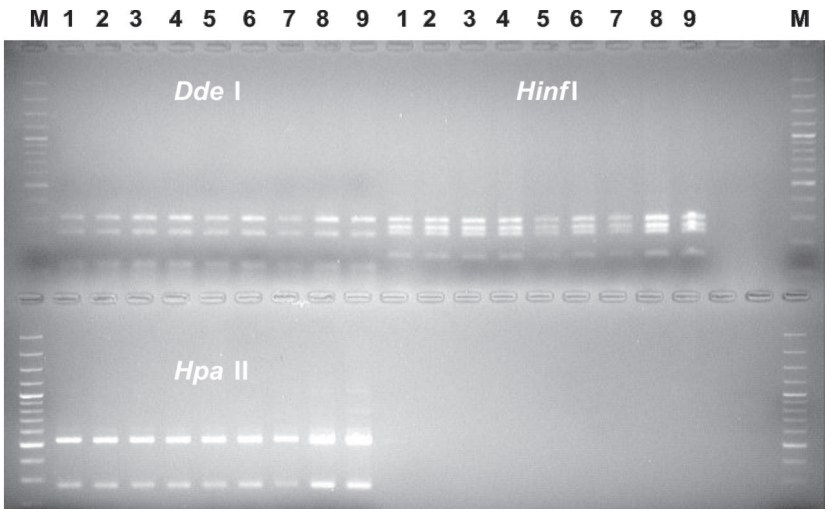

FIGURE 2 - PCR-RFLP of the 16S-23S rDNA spacer region digested with Dde I, Hinf I and Hpa II. (M) 100 bp marker (Fermentas), (1-3) bacteria isolated from leaves (IBSBF 2738, L21 and L-23, respectively); (4-5) from berries (IBSBF 2740, 2741); (6-7) from twigs (IBSBF 2739, TW17); controls: (8) IBSBF $1967^{\mathrm{P}}$ and (9) IBSBF 1926. ( $\mathrm{p}=$ pathovar reference strain).

\section{REFERENCES}

Destéfano SAL, Rodrigues Neto J (2002) Rapid differentiation of Xanthomonas strains causing disease in citrus plants by PCR-RFLP of the 16S-23S rDNA spacer region. Summa Phytopathologica 28:167-172

Freire FCO, Oliveira ADSO (2001) Ocorrência do cancro bacteriano da videira no Estado do Ceará. Fortaleza: EMBRAPA- 


\section{J. Rodrigues Neto et al.}

PA 2. Comunicado Técnico 62.

Halfeld-Vieira BA, Nechet KL (2006) Bacterial canker of grapevine in Roraima, Brazil. Fitopatologia Brasileira 31:604.

Lima MF, Ferreira MASV, Moreira WA, Dianese JC (1999) Bacterial canker of grapevine in Brazil. Fitopatologia Brasileira 24:440-443.

Malavolta Júnior VA, Almeida IMG, Sugimori MH, Ribeiro IJA, Rodrigues Neto J, Pires EJP, Nogueira EMC (1999a) Ocorrência de Xanthomonas campestris pv. viticola em videira no Brasil. Summa Phytopathologica 25:262-264.
Malavolta Júnior VA, Almeida IMG, Sugimori MH, Ribeiro IJA, Rodrigues Neto J, EJP \& Nogueira EMC (1999b) Xanthomonas campestris pv. viticola em videira no Estado do Piauí. Summa Phytopathologica 25:27. (Resumo)

Maniatis T, Fritsch EF, Sambrook J (1982) Molecular cloning: a laboratory manual. Cold Spring Harbor NY. Cold Spring Harbor Laboratory Press.

Pitcher DG, Saunders NA, Owen RJ (1989) Rapid extraction of bacterial genomic DNA with guanidium thiocyanate. Letters in Applied Microbiology 8:151-156.

TPP 205 - Received 4 November 2010 - Accepted 30 November 2010 Section Editor: Valmir Duarte 